\title{
EFFECTS OF ARSENIC AND PHOSPHORUS ON THE GROWTH AND NUTRIENT CONCENTRATION IN RICE PLANT
}

\author{
Howladar M. M., M. J. Uddin ${ }^{1}$, M. M. Islam ${ }^{1}$, Z. Parveen and M. K. Rahman \\ Department of Soil, Water and Environment, University of Dhaka, Dhaka 1000, Bangladesh; \\ ${ }^{1}$ Department of Soil and Environment, University of Barisal, Barisal, Bangladesh
}

\begin{abstract}
A pot experiment was carried out with arsenic (As) viz. $0,0.1,1$ and $2 \mathrm{mgL}^{-1}$ as sodium arsenite and phosphorus viz, 0,15 and $30 \mu \mathrm{gmL}^{-1}$ as ammonium dihydrogen phosphate to evaluate their effects on dry matter yield and nutrients concentration in rice plants (Oryza sativa L.) in the net house. Arsenic toxicity caused more damage to root than to shoot. As reduced plant height and dry matter yields but lower level increased the same significantly. A maximum diminution of $26.70 \%$ shoot weight and $32.30 \%$ root weights were observed where $2 \mathrm{mgL}^{-1} \mathrm{As}$ and $0 \mu \mathrm{gmL}^{-1} \mathrm{P}$ were applied. Micronutrients were found to be more strongly antagonized by arsenic than the macronutrients. Maximum and minimum accumulation of different nutrients was found at 30 $\mu \mathrm{gmL}^{-1}$ and $0 \mu \mathrm{gmL}^{-1} \mathrm{P}$ applications, respectively. The lowest concentration of most of the nutrients were found at $2 \mathrm{mgL}^{-1} \mathrm{As}$ and $0 \mu \mathrm{gmL}^{-1} \mathrm{P}$. Experiment revealed that the concentrations of nitrogen, potassium, sulphur, iron, copper, zinc and manganese in the root and shoot of rice plants showed an antagonistic effect with As and synergistic effect with $P$.
\end{abstract}

Key words: Arsenic; Phytotoxicity; Nutrients; Food chain; Accumulations.

\section{INTRODUCTION}

Arsenic is a potent environmental pollutant that has caused one of the largest public health poisonings in the history of human civilization (Islam and Hossain 2019). Arsenic contamination of paddy soils irrigated with arsenic-rich groundwater in Bangladesh is well documented (Meharg and Rahman 2003, Huq and Naidu 2003) and the risk of soil contamination is higher in the areas where the groundwater has elevated arsenic (Meharg and Rahman 2003, Huq 2008, Lu et al. 2009). The people of Bangladesh are not only drink the arsenic contaminated groundwater but also irrigate their crops. About $33 \%$ of total arable land of the country is under irrigation facilities. Irrigation is principally performed in dry season for boro rice cultivation. In Bangladesh, a large number of shallow tube well and deep tube well have been installed to irrigate about 4.3 million hectares of crop land which contributes to the food grain production of the country significantly (Rashid et al. 2004). The agricultural soil of arsenic non-

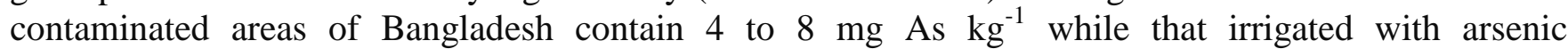
contaminated groundwater, contain up to $83 \mathrm{mg} \mathrm{As} \mathrm{kg}^{-1}$. The maximum acceptable concentration of arsenic in agricultural soil is $20 \mathrm{mg} \mathrm{kg}^{-1}$. Chowdhury et al. (2017) observed that the concentration of arsenic was higher in paddy soils compared to non-paddy soils, with soils irrigated with groundwater being higher in arsenic than those irrigated with surface water. At higher concentration, arsenic is toxic to most plants. It interferes with metabolic processes and inhibits plant growth and development through arsenic induced phytotoxicity. When plants are exposed to excess arsenic either in soil or in solution culture, they exhibits toxicity symptoms such as inhibition of seed germination (Abedin et al. 2002a), decrease in plant height (Abedin et al. 2002b, Jahan et al. 2003), depress in tillering (Rahman et al. 2004), reduction in root growth (Abedin et al. 2002a), decrease in shoot growth (Khan et al. 2010), lower fruit and grain yield (Abedin et al. 2002b; Panaullah et al. 2009) and sometimes, leads to death. Chowdhury et al. (2018) concluded that the paddy soils of different physiographic regions in Bangladesh had differences in their total, bioavailable and solid phase pool of arsenic. Recent studies have highlighted areas of Bangladesh where soil arsenic is elevated (Martin et al. 2014), however, these 
studies have not indicated the concentrations of arsenic in the soil available to plants, which is more important considering the food security and human health (Chowdhury et al. 2018).

The present study was carried out to evaluate the effects of As and $\mathrm{P}$ with 5 tonha $^{-1}$ water hyacinth compost on the growth and macro- and micro nutrient concentrations in rice plants.

Soil

\section{MATERIAL AND METHODS}

Surface sample (0 to $15 \mathrm{~cm}$ depth) was collected from Koroia union, Kochua upazila, under Chandpur district. Samples were air- dried, ground, sieved ( $<3 \mathrm{~mm}$ sieve) and kept in polyethylene bags. Water hyacinth was collected from the same location, cut into pieces, added few grammes of soil, saturated with water and kept in gunny bags under shaded condition. After, six weeks compost was ready. Some physicochemical properties of the soil were determined following standard methods. Soil had a $\mathrm{pH}\left(1: 2.5 \mathrm{w} / \mathrm{v} \mathrm{H}_{2} \mathrm{O}\right)$ of 6.28 , organic carbon $2.05 \%$, organic matter $3.53 \%$, available $\mathrm{N}, \mathrm{P}, \mathrm{K}$ and $\mathrm{S}$ were 299, 34, 26, and $92 \mathrm{mgkg}^{-1}$, respectively., total $\mathrm{N}, \mathrm{P}, \mathrm{K}$ and $\mathrm{S}$ were $0.19,0.13,0.25$ and $0.14 \%$ respectively., total $\mathrm{As}, \mathrm{Fe}, \mathrm{Zn}, \mathrm{Cu}$ and $\mathrm{Mn}$ were 3.0, 347, 25, 179 and $67 \mathrm{mgkg}^{-1}$, respectively., moisture content 20.7, sand 1.75 , silt 62.50 and clay $35.75 \%$ respectively and silty clay loam in texture. The concentration of some nutrients in water hyacinth compost was total $\mathrm{N} 0.75 \%$, total S $0.23 \%$, and total $\mathrm{As}, \mathrm{Fe}, \mathrm{Zn}, \mathrm{Cu}$ and $\mathrm{Mn}$ were $0.51,330,188,31.3$ and $68 \mathrm{mgkg}^{-1}$, respectively.

\section{Pot experiment}

Four kilogram of soil was used per plastic pot (height $22 \mathrm{~cm}$ and diameter $27 \mathrm{~cm}$ ). The pots were arranged in a completely randomized design (CRD).Four levels of arsenic (As) as sodium arsenite viz. 0, $0.1,1$ and $2 \mathrm{mg} \mathrm{L}^{-1}$ and three doses of phosphorus viz. 0,15 and $30 \mathrm{mgkg}^{-1}$ as ammonium dihydrogen phosphate were added. A basal dressing of $\mathrm{N}$ at the rate of $40 \mathrm{~kg} \mathrm{ha}^{-1}$ as urea, $\mathrm{K}$ at the rate of $20 \mathrm{kgha}^{-1}$ as muriate of potash and $\mathrm{S}$ at the rate of $5 \mathrm{kgha}^{-1}$ as gypsum and 5 tonha $^{-1}$ water hyacinth compost were added. Treatments were replicated three times. Arsenic was applied with irrigation water in the form of solution every alternate day. Three rice seedlings (BRRI- 48) of three weeks old were transplanted per pot. The height of the individual plant was measured from the soil level to the tip of the leaflet at 15-day intervals and only the values of 75,90 and 105 days are presented in Table 1.

\section{Harvesting and analysis}

Fifteen weeks old plants were harvested as root, shoot and grain. Roots were washed with tape water and finally with distilled water. Samples were oven-dried at $65^{\circ} \mathrm{C}$ in an oven for 72 hours. Dry weight of the samples were recorded, ground with a mechanical grinder and stored in air- tight polyethylene bags for chemical analysis. The concentration of nitrogen in shoot and root was determined by using micro Kjeldahl distillation method (Cresser and Parson 1979), phosphorus was determined following vanadomolybdophosphoric yellow colour method (Jackson 1965) at a wave length $430 \mathrm{~nm}$ using spectrophotometer model DR 5000, potassium was determined using Jenway flame photometer model PFP 7 and sulphur was determined by spectrophotometer (Klute 1986). The concentration of iron, copper, zinc and manganese were determined in the atomic absorption spectrometer (AAS) model Varian AA 240. Results were statistically analyzed using Microsoft Excel and Software Minitab 18.

\section{Height and dry matter yield}

\section{RESULTS AND DISCUSSION}

The average heights of rice plants were recorded at 75, 90 and 105 days after transplanting (Table 1). Results varied significantly ( $\mathrm{p}<0.05$ ). At 75, 90 and 105 days after transplantation, 1 and $2 \mathrm{mgkg}^{-1} \mathrm{As}$ treatments caused a significant reduction in plant height. The highest height of rice plant $(85 \mathrm{~cm})$ was 
recorded in $0.1 \mathrm{mgkg}^{-1}$ As treatment where $30 \mathrm{mgkg}^{-1}$ phosphorus was applied at 105 days after transplantation. The lowest height $(58 \mathrm{~cm})$ was observed in $2 \mathrm{mgkg}^{-1} \mathrm{As}$ where $0 \mathrm{mgkg}^{-1} \mathrm{P}$ was applied.

Table 1. Height of rice plants grown at different levels of As and $P$.

\begin{tabular}{|c|c|c|c|c|}
\hline \multirow{2}{*}{$\begin{array}{l}\text { As levels } \\
\left(\mathrm{mgkg}^{-1}\right)\end{array}$} & \multirow{2}{*}{$\begin{array}{c}\text { P levels } \\
\left(\mathrm{mgkg}^{-1}\right)\end{array}$} & \multicolumn{3}{|c|}{ Plant height $(\mathrm{cm})$} \\
\hline & & $75 d$ & 90d & $105 d$ \\
\hline \multirow[t]{3}{*}{0 (Control) } & 0 & $61^{b}$ & $78^{\mathrm{b}}$ & $81^{\mathrm{ab}}$ \\
\hline & 15 & $61^{\mathrm{b}}$ & $78^{\mathrm{c}}$ & $81^{\mathrm{b}}$ \\
\hline & 30 & $61^{\mathrm{bc}}$ & $78^{\mathrm{b}}$ & $81^{\mathrm{bc}}$ \\
\hline \multirow[t]{3}{*}{0.1} & 0 & $63^{\mathrm{a}}$ & $80^{\mathrm{a}}$ & $82^{\mathrm{a}}$ \\
\hline & 15 & $65^{\mathrm{a}}$ & $82^{\mathrm{a}}$ & $84^{\mathrm{a}}$ \\
\hline & 30 & $66^{\mathrm{a}}$ & $83^{\mathrm{a}}$ & $85^{\mathrm{a}}$ \\
\hline \multirow[t]{3}{*}{1} & 0 & $60^{\mathrm{b}}$ & $77^{b}$ & $80^{\mathrm{b}}$ \\
\hline & 15 & $62^{b}$ & $80^{\mathrm{b}}$ & $82^{\mathrm{b}}$ \\
\hline & 30 & $63^{b}$ & $82^{\mathrm{a}}$ & $83^{\mathrm{ab}}$ \\
\hline \multirow[t]{3}{*}{2} & 0 & $58^{\mathrm{c}}$ & $74^{c}$ & $78^{\mathrm{c}}$ \\
\hline & 15 & $60^{\mathrm{b}}$ & $77^{\mathrm{c}}$ & $79^{\mathrm{c}}$ \\
\hline & 30 & $60^{c}$ & $78^{\mathrm{b}}$ & $80^{c}$ \\
\hline
\end{tabular}

Plant growth was also influenced by phosphorus and it reached maximum level when $30 \mathrm{mgkg}^{-1} \mathrm{P}$ was applied. The progressive accumulation of arsenic (As) in plants with the time of exposure to As treatments caused the reduction of plant height (Barrachina et al. 1994). A reduction in plant height with increasing arsenic concentration was reported by Yamare (1989) in rice plants. Dry weights of shoot and root of rice plants are presented in Table 2 . The results varied significantly at $5 \%$ level.

Table 2. Dry matter production (g/pot) of rice plants at different levels of As and P.

\begin{tabular}{|c|c|c|c|c|c|c|}
\hline \multirow[t]{2}{*}{ As level $\left(\mathrm{mgkg}^{-1}\right)$} & \multicolumn{2}{|c|}{ Phosphorus $\left(0 \mathrm{mgkg}^{-1}\right)$} & \multicolumn{2}{|c|}{ Phosphorus ( $\left.15 \mathrm{mgkg}^{-1}\right)$} & \multicolumn{2}{|c|}{ Phosphorus (30 $\left.\mathrm{mgkg}^{-1}\right)$} \\
\hline & Shoot & Root & Shoot & Root & Shoot & Root \\
\hline 0 (Control) & $2.12^{\mathrm{b}}$ & $0.62^{\mathrm{b}}$ & $2.12^{\mathrm{d}}$ & $0.62^{\mathrm{b}}$ & $2.12^{\mathrm{b}}$ & $0.62^{\mathrm{d}}$ \\
\hline 0.1 & $2.25^{\mathrm{a}}$ & $0.66^{\mathrm{a}}$ & $2.47^{\mathrm{a}}$ & $0.71^{\mathrm{a}}$ & $2.90^{\mathrm{a}}$ & $0.77^{\mathrm{a}}$ \\
\hline 1 & $2.21^{\mathrm{a}}$ & $0.64^{\mathrm{ab}}$ & $2.37^{\mathrm{b}}$ & $0.69^{\mathrm{a}}$ & $2.41^{\mathrm{b}}$ & $0.70^{\mathrm{b}}$ \\
\hline 2 & $2.07^{\mathrm{b}}$ & $0.53^{\mathrm{c}}$ & $2.28^{\mathrm{c}}$ & $0.68^{\mathrm{a}}$ & $2.35^{\mathrm{b}}$ & $0.67^{\mathrm{c}}$ \\
\hline
\end{tabular}

The highest dry matter yields of shoot $(2.90 \mathrm{~g})$ and root $(0.77 \mathrm{~g})$ were obtained at $0.1 \mathrm{mgkg}^{-1} \mathrm{As}$ treatment where $30 \mathrm{mgkg}^{-1}$ phosphorus was used (Table 2). The lowest values for shoots $(2.07 \mathrm{~g})$ and roots were $(0.53 \mathrm{~g})$ obtained at $2 \mathrm{mgkg}^{-1}$ As where $0 \mathrm{mgkg}^{-1}$ phosphorus was applied (Table 2). Dry matter production varied significantly $(\mathrm{p}<0.05)$ in all As treatments. It was evident from the results that $1 \mathrm{mgkg}^{-1}$ As level was the threshold value to reduce the dry matter yields in rice plants. There was a further decrement in dry matter yield from 1 to $2 \mathrm{mgkg}^{-1} \mathrm{As}$ level. The results of the present investigation are in agreement with the findings of Paivoke (1983) in garden pea and Marin et al. (1992) in rice.

\section{Macronutrients (N P K S)}

The concentration of nitrogen in shoot and root of rice plants was affected by different levels of arsenic (Table 3). Data showed that nitrogen concentration in rice shoot and root at different arsenic treatments varied significantly $(\mathrm{p}<0.05)$. The nitrogen concentration ranged from 0.576 to $0.662 \%$ in shoot and 0.965 to $1.184 \%$ in root (Table 3$)$. The maximum concentration in both root $(1.184 \%)$ and shoot $(0.662 \%)$ were obtained at the $0 \mathrm{mgkg}^{-1}$ treatment of arsenic with different doses of phosphorous application. The minimum value was obtained at $2 \mathrm{mgkg}^{-1}$ treatment $(0.965 \%$ in root and $0.576 \%$ in 
shoot) of arsenic when $0 \mathrm{mgkg}^{-1}$ phosphorous was used. The decrease in nitrogen content with increasing arsenic treatment was found in many plant parts in rice (Yamare 1989) and in garden pea (Paivoke 1983). Merry et al.(1986) observed antagonistic effects between arsenic and nitrogen in silver beet.

The concentration of $\mathrm{P}$ in rice plants was affected by different levels of arsenic and varied significantly $(\mathrm{p}<0.05)$. In both shoot and root, the absorption of phosphorus was influenced by As. Arsenic interferes the activity of phosphorus in plants. Maximum phosphorus concentration $(0.172 \%)$ in root was obtained at $0.1 \mathrm{mgkg}^{-1} \mathrm{As}$ where $30 \mathrm{mgkg}^{-1}$ dose of $\mathrm{P}$ was applied (Table 3). The lowest value was recorded at $2 \mathrm{mgkg}^{-1} \mathrm{As}$ level which was $0.134 \%$ where $0 \mathrm{mgkg}^{-1} \mathrm{P}$ was applied (Table 3). In shoot, the maximum $\mathrm{P}$ concentration was obtained $(0.253 \%)$ at $0.1 \mathrm{mgkg}^{-1}$ As level where $30 \mathrm{mgkg}^{-1} \mathrm{P}$ was applied (Table 3 ) and the lowest value $\left(0.193 \%\right.$ ) was observed at $2 \mathrm{mgkg}^{-1}$ As treatment where $0 \mathrm{mgkg}^{-1}$ $\mathrm{P}$ was applied (Table 3). A strong antagonistic effect of As on P uptake in plants might be due to the act that arsenic behaves in soil-water system very much similar to that of phosphorus and was taken up by roots by the same mechanism as phosphorus (Wauchope 1983, Meharg and Maenair 1990). Phosphorus concentration was also reduced with increasing arsenic concentration in rice (Onken et al. 1995), in alfalfa (Khattak et al.1991), in bush bean (Wallace 1980) and in the leaf of cauliflower (Blatt 1990).

Potassium concentration in rice plants was affected by different levels of As and P (Tables 3). Results of shoot and root differed significantly $(\mathrm{p}<0.05)$. The range for $\mathrm{K}$ content of rice plants was found to be a from 0.1287 to $0.3634 \%$ in roots. The ranges for potassium content in shoot were 1.8598 to $2.5604 \%$. Arsenic was found to reduce potassium content significantly in rice plants at different levels of As in shoot. Maximum potassium concentration in root was obtained at $0 \mathrm{mgkg}^{-1} \mathrm{As}$ in the nutrient solution where 0,15 and $30 \mathrm{mgkg}^{-1}$ doses of $\mathrm{P}$ was applied separately and the highest concentration of potassium was $0.3634 \%$. The lowest value was measured at $2 \mathrm{mgkg}^{-1} \mathrm{As}$ level which was $0.1287 \%$ where $15 \mathrm{mgkg}^{-}$ ${ }^{1} \mathrm{P}$ was applied (Table 3). In shoot, the maximum potassium concentration was obtained $(2.5604 \%)$ at 0 $\mathrm{mgkg}^{-1} \mathrm{As}$ level where 0,15 and $30 \mathrm{mgkg}^{-1} \mathrm{P}$ was applied separately and the lowest value $(1.8598 \%)$ was observed at $2 \mathrm{mgkg}^{-1} \mathrm{As}$ treatment where $15 \mathrm{mgkg}^{-1} \mathrm{P}$ was applied. Arsenic-potassium antagonistic interaction was found in capsicum (Karimian et al. 1983), in rice (Yamare1989) and in the root of bush bean (Wallace et al.1980).

The highest and lowest concentrations of sulphur in rice roots were observed at $0.1 \mathrm{mgkg}^{-1}$ and 2 $\mathrm{mgkg}^{-1}$ As treatment where $0 \mathrm{mgkg}^{-1}$ and $15 \mathrm{mgkg}^{-1} \mathrm{P}$ was applied, respectively and the highest value was $0.6025 \%$ and the lowest value was $0.2878 \%$ (Tables 3 ). Results varied significantly ( $\mathrm{p}<0.05)$ in root and shoot. The ranges of sulphur content in root and shoot were 0.2878 to $0.6025 \%$ and 0.2510 to $0.2969 \%$ respectively. In rice root and shoot As levels caused significant decrease in sulfur concentration. In shoots, the maximum sulphur concentration was obtained (0.2969\%) at $0.1 \mathrm{mgkg}^{-1} \mathrm{As}$ level where $15 \mathrm{mgkg}^{-1} \mathrm{P}$ was applied and the lowest value $(0.2510 \%)$ was observed at $1 \mathrm{mgkg}^{-1} \mathrm{As}$ treatment where $0 \mathrm{mgkg}^{-1} \mathrm{P}$ was applied. Merry et al. (1986), Kitagishi and Yamare (1981) reported that there is an interaction between $\mathrm{S}$ and As. Arsenic blocks the sites of sulfur in thio-enzymes. Jahan et al. (2003) performed a pot experiment on the accumulation of arsenic in rice plants and its effects on nutrient uptake viz. N, P, K, Ca, Fe and Zn using 7 levels of arsenic namely 0, 10, 20, 30, 40, 50 and 60 $\mathrm{mgkg}^{-1}$ soil and found that arsenic resulted in decreasing the uptake of most of the above plant nutrients. They also recorded the content of arsenic was higher in rice root than that of shoots.

\section{Micronutrients (Fe Cu Zn Mn)}

The concentration of micronutrients viz. iron, copper, zinc and manganese are presented in Table 4. Iron is the only element observed which was synergized by arsenic. Iron concentrations in root were in the range of 12918 to $31245 \mathrm{mgkg}^{-1}$ and in shoot from 614 to $1047 \mathrm{mgkg}^{-1}$. Results varied significantly $(\mathrm{p}<0.05)$. The highest and lowest concentrations of iron in rice roots were recorded at $0.1 \mathrm{mgkg}^{-1} \mathrm{As}$ 
where $30 \mathrm{mgkg}^{-1}$ and $15 \mathrm{mgkg}^{-1} \mathrm{P}$ was applied respectively, the highest value was $31245 \mathrm{mgkg}^{-1}$ and the lowest value was $12918 \mathrm{mgkg}^{-1}$. Root accumulated more Fe than shoot. Its concentrations in root was about two times than that of shoot. In shoot, the lowest value of iron was $614 \mathrm{mgkg}^{-1}$ at $1 \mathrm{mgkg}^{-1} \mathrm{As}$ level where $0 \mathrm{mgkg}^{-1} \mathrm{P}$ was applied and the highest value of iron was $1047 \mathrm{mgkg}^{-1}$ at $2 \mathrm{mgkg}^{-1} \mathrm{As} \mathrm{level}^{-1}$ where $30 \mathrm{mgkg}^{-1} \mathrm{P}$ was applied. Arsenic-iron synergisms were reported previously in rice plants (Yamare1989) and in tomato plants (Barrachina et al. 1994). Yamare (1989) also found an increase in Fe concentration in rice with the increase of arsenic concentrations.

Table 3. The concentration of macronutrients in shoot and root of rice plants at different levels of As and P.

\begin{tabular}{|c|c|c|c|c|c|c|c|c|c|c|c|c|c|}
\hline \multirow{2}{*}{$\left.\begin{array}{c}\text { As } \\
\text { level } \\
(\mathrm{mg}\end{array}\right)$} & \multirow{2}{*}{$\begin{array}{c}\text { Shoot } \\
\& \\
\text { root }\end{array}$} & \multicolumn{4}{|c|}{ Phosphorus (0 mgkg $\left.^{-1}\right)$} & \multicolumn{4}{|c|}{ Phosphorus (15 $\mathrm{mgkg}^{-1}$ ) } & \multicolumn{4}{|c|}{ Phosphorus (30 $\mathrm{mgkg}^{-1}$ ) } \\
\hline & & $\begin{array}{c}\mathbf{N} \\
(\%)\end{array}$ & $\begin{array}{c}\mathbf{P} \\
(\%)\end{array}$ & $\begin{array}{c}\mathbf{K} \\
(\%)\end{array}$ & $\begin{array}{c}S \\
(\%)\end{array}$ & $\begin{array}{c}\mathbf{N} \\
(\%)\end{array}$ & $\begin{array}{c}\mathbf{P} \\
(\%)\end{array}$ & $\begin{array}{c}\mathbf{K} \\
(\%)\end{array}$ & $\begin{array}{c}S \\
(\%)\end{array}$ & $\begin{array}{l}\mathrm{N} \\
(\%)\end{array}$ & $\begin{array}{c}\mathbf{P} \\
(\%)\end{array}$ & $\begin{array}{c}\mathbf{K} \\
(\%)\end{array}$ & $\begin{array}{c}\mathbf{S} \\
(\%)\end{array}$ \\
\hline \multirow[t]{2}{*}{$0^{*}$} & Shoot & $0.662^{\mathrm{a}}$ & $0.242^{\mathrm{a}}$ & $2.5604^{\mathrm{a}}$ & $0.2750^{\mathrm{a}}$ & $0.662^{\mathrm{a}}$ & $0.242^{\mathrm{a}}$ & $2.5604^{\mathrm{a}}$ & $0.2750^{\mathrm{b}}$ & $0.662^{\mathrm{a}}$ & $0.242^{b}$ & $2.5604^{\mathrm{a}}$ & $0.2750^{\mathrm{b}}$ \\
\hline & Root & $1.184^{\mathrm{a}}$ & $0.161^{\mathrm{a}}$ & $0.3634^{\mathrm{a}}$ & $0.5816^{\mathrm{b}}$ & $1.184^{\mathrm{a}}$ & $0.161^{\mathrm{ab}}$ & $0.3634^{\mathrm{a}}$ & $0.5816^{\mathrm{a}}$ & $1.184^{\mathrm{a}}$ & $0.161^{\mathrm{ab}}$ & $0.3634^{\mathrm{a}}$ & $0.5816^{\mathrm{a}}$ \\
\hline \multirow[t]{2}{*}{0.1} & Shoot & $0.621^{\mathrm{b}}$ & $0.243^{\mathrm{a}}$ & $2.3352^{\mathrm{a}}$ & $0.2729^{\mathrm{a}}$ & $0.635^{b}$ & $0.251^{\mathrm{a}}$ & $2.2601^{b}$ & $0.2969^{\mathrm{a}}$ & $0.645^{\mathrm{a}}$ & $0.253^{\mathrm{a}}$ & $2.3102^{\mathrm{a}}$ & $0.2838^{\mathrm{a}}$ \\
\hline & Root & $1.067^{\mathrm{b}}$ & $0.169^{\mathrm{a}}$ & $0.1558^{\mathrm{bc}}$ & $0.6025^{\mathrm{a}}$ & $1.112^{\mathrm{b}}$ & $0.171^{\mathrm{a}}$ & $0.2879^{\mathrm{b}}$ & $0.3405^{\mathrm{b}}$ & $1.134^{\mathrm{a}}$ & $0.172^{\mathrm{a}}$ & $0.2498^{\mathrm{b}}$ & $0.5283^{\mathrm{c}}$ \\
\hline \multirow[t]{2}{*}{1} & Shoot & $0.593^{\mathrm{bc}}$ & $0.209^{b}$ & $2.4603^{\mathrm{a}}$ & $0.2510^{\mathrm{c}}$ & $0.605^{\mathrm{c}}$ & $0.212^{\mathrm{b}}$ & $2.0851^{\mathrm{bc}}$ & $0.2772^{b}$ & $0.612^{\mathrm{b}}$ & $0.223^{\mathrm{c}}$ & $2.0349^{b}$ & $0.2903^{\mathrm{a}}$ \\
\hline & Root & $0.997^{\mathrm{c}}$ & $0.148^{\mathrm{b}}$ & $0.1758^{\mathrm{b}}$ & $0.4497^{\mathrm{d}}$ & $1.002^{\mathrm{c}}$ & $0.151^{b c}$ & $0.1358^{c}$ & $0.3449^{b}$ & $1.023^{\mathrm{b}}$ & $0.152^{\mathrm{bc}}$ & $0.2278^{b c}$ & $0.5384^{\mathrm{b}}$ \\
\hline \multirow[t]{2}{*}{2} & Shoot & $0.576^{\mathrm{c}}$ & $0.193^{\mathrm{c}}$ & $1.9098^{b}$ & $0.2619^{b}$ & $0.594^{\mathrm{c}}$ & $0.199^{\mathrm{b}}$ & $1.8598^{\mathrm{c}}$ & $0.2598^{\mathrm{c}}$ & $0.605^{\mathrm{b}}$ & $0.212^{\mathrm{d}}$ & $2.0051^{\mathrm{b}}$ & $0.2532^{c}$ \\
\hline & Root & $0.965^{\mathrm{c}}$ & $0.134^{\mathrm{c}}$ & $0.1453^{c}$ & $0.5741^{\mathrm{c}}$ & $0.983^{\mathrm{c}}$ & $0.145^{\mathrm{c}}$ & $0.1287^{c}$ & $0.2878^{b}$ & $0.992^{\mathrm{b}}$ & $0.148^{\mathrm{c}}$ & $0.2178^{\mathrm{c}}$ & $0.4104^{\mathrm{d}}$ \\
\hline
\end{tabular}

Concentration of $\mathrm{Cu}$ in rice root and shoot varied from 21 to $71 \mathrm{mgkg}^{-1}$ and 1610 to $2532 \mathrm{mgkg}^{-1}$, respectively. Shoot accumulated more copper than root. Maximum copper concentration in root was observed under $0.1 \mathrm{mgkg}^{-1}$ As treatment where $0 \mathrm{mgkg}^{-1} \mathrm{P}$ was applied and the highest value of copper was $71 \mathrm{mgkg}^{-1}$, while in shoot, maximum copper concentration $\left(2532 \mathrm{mgkg}^{-1}\right.$ ) was observed at 0.1 $\mathrm{mgkg}^{-1}$ As treatment where $15 \mathrm{mgkg}^{-1} \mathrm{P}$ was applied. A significant decrease in copper content in root was obtained from $2 \mathrm{mgkg}^{-1} \mathrm{As}$ treatment where $15 \mathrm{mgkg}^{-1} \mathrm{P}$ was applied and the lowest value of copper was $21 \mathrm{mgkg}^{-1}$. In case of shoot, a significant decrease was found from $2 \mathrm{mgkg}^{-1} \mathrm{As}$ where $15 \mathrm{mgkg}^{-1} \mathrm{P}$ was applied and the value was $1610 \mathrm{mgkg}^{-1}$. Results varied significantly $(\mathrm{p}<0.05)$ for root and shoot. It was observed that arsenic influenced the concentration of copper in rice plants. The results of the present investigation support the earlier findings of Barrachina et al. (1994) who observed a decrease in $\mathrm{Cu}$ content in tomato plants with increasing As concentration in culture solution. Results showed that arsenic antagonised absorption of copper in both root and shoot of rice plants (Table 4). Lonergan and Asher (1967) found the existence of $\mathrm{P}-\mathrm{Cu}$ interaction regarding the uptake of $\mathrm{Cu}$ by the root.

Table 4. The concentration of micronutrients in shoot and root of rice plants at different levels of As and P.

\begin{tabular}{|c|c|c|c|c|c|c|c|c|c|c|c|c|c|}
\hline \multirow[b]{2}{*}{$\begin{array}{c}\text { As level } \\
\left(\mathrm{mg} \mathrm{kg}^{-1}\right)\end{array}$} & \multirow[b]{2}{*}{$\begin{array}{c}\text { Shoot } \\
\& \\
\text { root }\end{array}$} & \multicolumn{4}{|c|}{ Phosphorus (0 mgkg $\left.{ }^{-1}\right)$} & \multicolumn{4}{|c|}{ Phosphorus (15 mgkg $\left.^{-1}\right)$} & \multicolumn{4}{|c|}{ Phosphorus (30 $\left.\mathrm{mgkg}^{-1}\right)$} \\
\hline & & $\begin{array}{c}\mathrm{Fe} \\
(\mathrm{mg} \\
\left.\mathrm{kg}^{-1}\right)\end{array}$ & $\begin{array}{c}\mathrm{Cu} \\
(\mathrm{mg} \\
\left.\mathbf{k g}^{-1}\right)\end{array}$ & $\begin{array}{c}\mathrm{Zn} \\
(\mathrm{mg} \\
\left.\mathrm{kg}^{-1}\right)\end{array}$ & $\begin{array}{l}\mathrm{Mn} \\
(\mathrm{mg} \\
\left.\mathrm{kg}^{-1}\right)\end{array}$ & $\begin{array}{c}\mathrm{Fe} \\
(\mathrm{mg} \\
\left.\mathrm{kg}^{-1}\right)\end{array}$ & $\begin{array}{c}\mathrm{Cu} \\
(\mathrm{mg} \\
\left.\mathrm{kg}^{-1}\right)\end{array}$ & $\begin{array}{c}\mathrm{Zn} \\
(\mathrm{mg} \\
\left.\mathrm{kg}^{-1}\right)\end{array}$ & $\begin{array}{l}\mathrm{Mn} \\
(\mathrm{mg} \\
\left.\mathrm{kg}^{-1}\right)\end{array}$ & $\begin{array}{c}\mathrm{Fe} \\
(\mathrm{mg} \\
\left.\mathrm{kg}^{-1}\right)\end{array}$ & $\begin{array}{c}\mathrm{Cu} \\
(\mathrm{mg} \\
\left.\mathrm{kg}^{-1}\right)\end{array}$ & $\begin{array}{c}\mathrm{Zn} \\
(\mathrm{mg} \\
\left.\mathrm{kg}^{-1}\right)\end{array}$ & $\begin{array}{r}\mathrm{Mn} \\
(\mathrm{mg} \\
\left.\mathrm{kg}^{-1}\right)\end{array}$ \\
\hline \multirow[t]{2}{*}{$0 *$} & Shoot & $699^{c}$ & $2412^{\mathrm{a}}$ & $1054^{\mathrm{a}}$ & $333^{d}$ & $699^{d}$ & $2412^{a}$ & $1054^{\mathrm{a}}$ & $333^{\mathrm{d}}$ & $699^{d}$ & $2412^{a}$ & $1054^{\mathrm{a}}$ & $333^{d}$ \\
\hline & Root & $29118^{a}$ & $68^{\mathrm{a}}$ & $226^{\mathrm{a}}$ & $582^{\mathrm{a}}$ & $29118^{a}$ & $68^{\mathrm{a}}$ & $226^{\mathrm{a}}$ & $582^{\mathrm{a}}$ & $29118^{\mathrm{ab}}$ & $68^{\mathrm{a}}$ & $226^{\mathrm{a}}$ & $582^{\mathrm{a}}$ \\
\hline \multirow[t]{2}{*}{0.1} & Shoot & $958^{\mathrm{a}}$ & $2212^{b}$ & $981^{b}$ & $721^{\mathrm{a}}$ & $922^{\mathrm{a}}$ & $2532^{\mathrm{a}}$ & $890^{\mathrm{b}}$ & $653^{\mathrm{a}}$ & $918^{\mathrm{b}}$ & $2322^{b}$ & $870^{b}$ & $828^{\mathrm{a}}$ \\
\hline & Root & $20938^{b}$ & $71^{\mathrm{a}}$ & $193^{b}$ & $532^{\mathrm{b}}$ & $12918^{b}$ & $32^{\mathrm{b}}$ & $114^{\mathrm{b}}$ & $513^{\mathrm{b}}$ & $31245^{\mathrm{a}}$ & $29 d$ & $120^{\mathrm{b}}$ & $550^{\mathrm{b}}$ \\
\hline \multirow[t]{2}{*}{1} & Shoot & $614^{\mathrm{d}}$ & $1923^{c}$ & $779^{c}$ & $526^{b}$ & $821^{\mathrm{c}}$ & $2102^{b}$ & $750^{\mathrm{c}}$ & $573^{b}$ & $759^{c}$ & $2243^{c}$ & $740^{\mathrm{c}}$ & $588^{b}$ \\
\hline & Root & $28658^{\mathrm{a}}$ & $30^{\mathrm{b}}$ & $164^{\mathrm{c}}$ & $487^{\mathrm{c}}$ & $17218^{b}$ & $23^{c}$ & $94^{c}$ & $423^{c}$ & $27317^{\mathrm{ab}}$ & $54^{\mathrm{b}}$ & $99^{c}$ & $530^{c}$ \\
\hline \multirow[t]{2}{*}{2} & Shoot & $807^{\mathrm{b}}$ & $1610^{\mathrm{d}}$ & $679^{d}$ & $446^{c}$ & $830^{b}$ & $2032^{b}$ & $650^{d}$ & $538^{c}$ & $1047^{\mathrm{a}}$ & $1965^{\mathrm{d}}$ & $634^{d}$ & $398^{\mathrm{c}}$ \\
\hline & Root & $23034^{b}$ & $25^{c}$ & $159^{d}$ & $334^{\mathrm{d}}$ & $15617^{b}$ & $21^{\mathrm{c}}$ & $83^{\mathrm{d}}$ & $354^{\mathrm{d}}$ & $24214^{b}$ & $35^{\mathrm{c}}$ & $82^{d}$ & $337^{\mathrm{d}}$ \\
\hline
\end{tabular}


Zinc concentration in rice root and shoot was affected by arsenic treatments (Tables 4 ). The results differed significantly $(\mathrm{p}<0.05)$. Zinc concentration varied in rice root and shoot from 82 to $226 \mathrm{mgkg}^{-1}$ and 1054 to $634 \mathrm{mgkg}^{-1}$. The maximum concentration of $\mathrm{Zn}$ in rice root $\left(226 \mathrm{mgkg}^{-1}\right)$ was obtained at 0 $\mathrm{mgkg}^{-1} \mathrm{As}$ treatment where $0 \mathrm{mgkg}^{-1} \mathrm{P}$ was applied. The lowest concentration of zinc in rice root (82 $\mathrm{mgkg}^{-1}$ ) was recorded at $2 \mathrm{mgkg}^{-1}$ As treatment where $30 \mathrm{mgkg}^{-1} \mathrm{P}$ was used. It was observed that $\mathrm{Zn}$ concentration in root was significantly different with different doses of As treatment and zinc concentrations in the shoot of rice plants differed significantly $(\mathrm{p}<0.05)$. The maximum concentration of $\mathrm{Zn}$ in rice shoot $\left(1054 \mathrm{mgkg}^{-1}\right)$ was obtained at $0 \mathrm{mgkg}^{-1} \mathrm{As}$ treatment where $0 \mathrm{mgkg}^{-1} \mathrm{dose}$ of $\mathrm{P}$ was applied. The lowest concentration of zinc in rice shoot $\left(634 \mathrm{mgkg}^{-1}\right)$ was measured at $2 \mathrm{mgkg}^{-1} \mathrm{As}^{-1}$ treatment where $30 \mathrm{mgkg}^{-1} \mathrm{P}$ was added. It was observed that $\mathrm{Zn}$ concentrations in shoot varied significantly $(\mathrm{p}<0.05)$. The antagonistic effect of As on $\mathrm{Zn}$ was reported by Barrachina et al. (1994) in tomato plants. Heidaryan et al. (2011) observed an antagonistic interaction of $\mathrm{Zn}$ and P. Yoshida and Tanaka (1969) reported that normal rice plants became zinc deficient with the addition of $0.5 \%$ cellulose to the soil. Experiments of Forno et al. (1975), and Mikkelsen and Brandon (1972) also showed that addition of readily decomposable organic materials may aggravate zinc deficiency and reduce zinc uptake by rice plants.

Manganese concentrations in rice root and shoot were affected by different levels of arsenic and are presented in Table 4. Results of root and shoot varied significantly $(\mathrm{p}<0.05)$. The ranges of $\mathrm{Mn}$ concentration in root and shoot were 334 to $582 \mathrm{mgkg}^{-1}$ and 333 to $828 \mathrm{mgkg}^{-1}$, respectively. It was found that $\mathrm{Mn}$ concentration declined with increasing levels of As in rice root and shoot. Manganese concentration in the shoot of rice plants was reduced from $0.1 \mathrm{mgkg}^{-1} \mathrm{As}$ to $2 \mathrm{mgkg}^{-1} \mathrm{As}^{\mathrm{dose}}$ significantly $(\mathrm{p}<0.05)$. Manganese concentration also reduced from $0.1 \mathrm{mgkg}^{-1}$ As to $0 \mathrm{mgkg}^{-1} \mathrm{As}$ dose application in the shoot of rice plants. The highest concentration of Mn was found $582 \mathrm{mgkg}^{-1}$ in the root of rice plants where $0 \mathrm{mgkg}^{-1} \mathrm{As}$ and $0 \mathrm{mgkg}^{-1} \mathrm{P}$ was applied. Arsenic (As) treatments differed significantly with the control, while $2 \mathrm{mgkg}^{-1} \mathrm{As}$ treatment differed significantly $(\mathrm{p}<0.05)$ with all other treatments and caused a decrease in Mn concentration in the root of rice plants. In rice shoot, the maximum concentration of $\mathrm{Mn}$ was obtained again at $0.1 \mathrm{mgkg}^{-1} \mathrm{As}$ treatment, then decreased in $\mathrm{Mn}$ concentration with increase in As concentration. Arsenic concentration of $1 \mathrm{mgkg}^{-1}$ differed significantly from $0.1 \mathrm{mgkg}^{-1}$ treatment, while $2 \mathrm{mgkg}^{-1}$ As differed significantly compared to the control and 0.1 $\mathrm{mgkg}^{-1}$ arsenic treatment. Such antagonistic effect of As on Mn uptake was reported in tomato plants by Barrachina et al. (1994) and in rice plants by Yamare (1989).

The experiment revealed that arsenic reduced the growth of rice plants and the concentrations of nitrogen, potassium, sulphur, iron, copper, zinc and manganese were antagonized by arsenic. The concentration of micronutrients was affected more severely than those of the macronutrients. Therefore, the concentration of arsenic in the soils might be an additional strategy for a more rational agricultural program.

\section{REFERENCES}

Abedin, M. J. and A. A. Meharg. 2002a. Relative toxicity of arsenite and arsenate on germination and early seedling growth of rice (Oryza sativa L.). Plant Soil. 243: 57-66.

Abedin, M. J., J. Cottep-Howells and A. A. Meharg. 2002b. Arsenic uptake and accumulation in rice (Oryza sativa L.) irrigated with contaminated water. Plant Soil. 240: 311-319.

Barrachina, A. C., F. B. Carbonell and J. M. Beneyto. 1994. Effects of Arsenic on the concentration of micronutrients in tomato plants grown in hydroponic culture. J. Plant Nutri. 17(11): 1887-1903. 
Blatt, C. R. 1990. Effects of arsenic and molybdenum on plant response of cauliflower grown in sand culture. Development Plant Soil Sci. 41: 303-306.

Chowdhury, M. T. A., C. M. Deacon, E. Steel, S. M. I. Huq, G. I. Paton, A. H. Price, P. N. Williams, A. A. Meharg and G. J. Norton. 2018. Physiological variability in arsenic dynamics in Bangladesh soils. Sci. Total Environ. 612: 1365-1372.

Chowdhury, M. T. A., C. M. Deacon, G. D. Jones, S. M. I. Huq, P. N. Williams, L. H. E. Winkel, A. H. Price, G. J. Norton and A. A. Meharg. 2017. Arsenic in Bangladesh soils related to physiographic region, paddy management, and micro- and macro-elemental status. Sci. Total Environ. pp. 406415.

Fazal, M. A., T. Kawachi and E. Ichio. 2001. Validity of the latest research findings on causes of groundwater arsenic contamination in Bangladesh. Water Int. 26(2): 380-389.

Cresser, M. S. and J. W. Parsons. 1979. Sulphuric-perchloric acid digestion of plant material for the determination of nitrogen, phosphorus, potassium, calcium and magnesium. Anal. Chim. Acta 109: 431-436.

Forno, D. A., S. Yoshida and C. J. Asher. 1975. Zinc deficiency in rice. Plant and Soil. 42(3): 537-550.

Heidaryan, E., T. Hatami, M. Rahimi and J. Moghadasi. 2011. Viscosity of pure carbon dioxide at supercritical region: Measurement and correlation approach. J. Supercritical Fluids. 56(2): 144151.

Huq, S. M. I. 2008. Fate of arsenic in irrigation water and its potential impacts on food chain. In: S.Ahuja, (ed.). Arsenic contamination of Groundwater: Mechanism, Analysis and Remediation. Willey, Hoboken., pp. 23-49.

Huq, S. M. I. and R. Naidu. 2003. Arsenic in ground water of Bangladesh: contamination in the food chain. In: M. F. Ahmed (ed.). Arsenic contamination: Bangladesh perspective. ITN-Bangladesh; Centre for water supply and management. BUET, Dhaka, Bangladesh.

Islam, K. and K. Hossain. 2019. Association between arsenic exposure and organ dysfunction- a population based study in Bangladesh. Abstract. $1^{\text {st }}$ International Conference on Environmental Science and Resource Management. 2019: Safe Environment for Better Living, February 08- 09, 2019. Mawlana Bhashani Science and Technology Universitry, ICESRM 2019., pp. 43-44.

Jackson, M. L. 1965. Soil Chemical Analysis. Prentice-Hall, Englewood Cliffs, NJ.pp. 498.

Jahan, I., S. Hoque, S. M. Ullah, M. G. Kibria. 2003. Effects of arsenic on some growth parameters of rice plant. Dhaka Univ. J. Biol. Sci.12: 71- 77.

Jahan, I., S. M. Ullah, S. Hoque and T. K. Ullah. 2003. Effects of arsenic on the mineral nutrition of rice plant. Dhaka Univ. J. Biol. Sci. 12(2): 165-175.

Karimian-Teherani, D., I. Kiss, H. Altmann, G. Wallisch and K. Kapeller. 1983. Accumulation and distribution of elements in plants (paprika). Acta-Alimentaria. 12(4): 301-318.

Khan, M. A., J. Stroud, Y. G. Zhu, S. P. McGrath and F. J. Zhao. 2010. Arsenic bioavailability to rice is elevated in Bangladeshi paddy soils. Environ. Sci. Technol. 44: 8515-8521.

Khattak, R. A., A. L. Page, D. R. Parker and D. Bakhtar. 1991. Accumulation and interactions of arsenic, selenium, molybdenum and phosphorous in Alfalfa. J. Environ. Quality. 20: 165-168.

Klute, A. 1986. Methods of Soil Analysis. Series 9. Am. Soc. Agron. Publ. Madison, WI, USA. 
Lonergan, J. F. and C. J. Asher. 1967. Response of plants to phosphate absorption and its relation to growth. Soil Sci.103: 311-318.

Lu, Y., E. E. Adomako, A. R. M. Solaiman, M. R. Islam, C. Deacon, P. N. Williams, G. K. M. M. Rahman and A. A. Meharg. 2009. Baseline soil variation is a major factor in arsenic accumulation in Bengal Delta paddy rice. Environ. Sci. Technol. 43(6): 1724-1729.

Marin, A. R., P. H. Masscheleyn, and W. H. Patrick. 1992. The influence of chemical form and concentration of arsenic on rice growth and tissue arsenic concentration. Plant Soil. 139:175-183.

Martin, M., E. Bonifacio, K. M. J. Hossain, S. M. I. Huq and E. Barberis. 2014. Arsenic fixation and mobilization in the soils of the Ganges and Meghna floodplains: Impact of pedoenvironmental properties. Geoderma 228-229: 132-141.

Meharg, A. A. and M.M. Rahman. 2003. Arsenic Contamination of Bangladesh Paddy Field Soils: Implications for Rice Contribution to Arsenic Consumption. Environ. Sci. Tech. 37: 229-234.

Merry, R. H., K. G. Tiller and A. M. Alston. 1986. The effects of soil contamination with copper, lead and arsenic on the growth and composition of plants 1. Effects of season, genotype, soil temperature and fertilizer. Plant Soil. 95: 225-268.

Mikkelsen, D. S. and D. M. Brandon. 1972. Zinc deficiency in the soil-water-rice plant system. Proc. 14. Rice Tech. working Group., pp. 81-82.

Onken, B. M. and L. R. Hossner. 1995. Plant uptake and determination of arsenic species in soil solution under flooded conditions. J. Environ. Quality. 24(2): 373-381.

Paivoke, A. 1983. The term effect of lead and arsenate on the growth and development, chlorophyll content and nitrogen fixation of the garden pea. Annales. Botanici. Fennici. 20(3): 297-306.

Panaullah, G. M., T. Alam, M. B. Hossain, R. H. Loppert, J. G. Lauren, C. A. Meisner, Z. U. Ahmed and J. M. Duxbury. 2009. Arsenic toxicity to rice (Oryza sativa L.) in Bangladesh. Plant Soil. 317(1-2): 31-39.

Rahman, M. A., M. M. Rahman, M. A. M. Miah and H. M. Khaled. 2004. Influence of soil arsenic concentrations in rice (Oryza sativa L.). J. Sub-trop. Agric. Res. Dev. 2: 24-31.

Rashid, H. A., D. K. Nath, M. Hossain, M. U. Khan, A. L. Shah, M. A. Saleque, M. S. Rahman and M. A. Ghani. 2004. Variation of arsenic content in groundwater with depth and river distance: GIS mapping. In: Latif Shah, et al. (eds.). Arsenic in the food chain: assessment of arsenic in the watersoil-crop systems. BRRI, Gazipur, Bangladesh., pp. 53-71.

Wallace, A., R. T. Mucller and R. A. Wood. 1980. Arsenic phytotoxicity and interactions. In: bush bean plants grown in solution culture. J. Agric. Food Chem. 16: 17-20.

Wauchope, R. D. 1983. Uptake, translocation and phytotoxicity of arsenic in plants. In: Lederer and Fensterheim (eds.). Arsenic: Industrial, Biomedical, Environment Perspectives. Arsenic Symposium. Gaiothersburg. MD., pp. 348-374.

Yamare, T. 1989. Mechanism and counter measures of arsenic toxicity to rice plant. Bulletin of the Shimane Agricultural Experiment Station, Japan., pp. 96-104.

Yoshida, S. and A. Tanaka. 1969. Zinc deficiency of the rice plant in calcareous soils. Soil Science and Plant Nutrition. 15(2): 75-80. 